\title{
Success Story of Common Bean Technology Pre-Scaling Up in Southern Ethiopia
}

\author{
Zekarias Bassa*, Melese Alemu and Bereket Zeleke \\ Southern Agricultural Research Institute, Agricultural Research center, Ethiopia
}

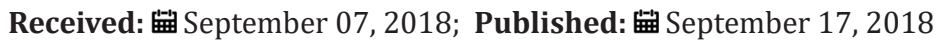

*Corresponding author: Zekarias Bassa, Irish-Aid Operational Research Technology Dissemination Project (ORTDP) Project, Southern Agricultural Research Institute, Areka, Agricultural Research center, P.O. Box 79

\section{Introduction}

Pulses grown in 2016/17 (2009 E.C.) covered 12.33\% $(1,549,911.86$ hectares) of the grain crop area and $9.69 \%$ (about $28,146,331.73$ quintals) of the grain production was drawn from the same crops. Faba beans, haricot beans (white), haricot beans (red), and chick peas were planted to $3.40 \%$ (about 427,696.80 hectares), $0.63 \%$ (about 78,910.13 hectares), 1.68\% (about 211,292.30 hectares) and 1.79\% (about 225,607.53 hectares) of the grain crop area. The production obtained from faba beans, haricot beans (white) haricot beans (red) and chick peas was $3.02 \%$ (about 8,780,108.79 quintals), 0.43\% (about 1,259,801.75 quintals), $1.23 \%(3,579,424.75$ quintals $)$ and $1.53 \%(4,441,459.26$ quintals) of the grain production, in that order CSA [1]. Common bean (Phaseolus vulgaris L.) is the second most important source of human dietary calories and also it has a high nutritional value with important protein contents $(\sim 22 \%)$, minerals (calcium, copper, iron, magnesium, manganese, zinc), and vitamins necessary to warrant the food security of people in the developing countries Misgana and Taddese [2].

Production of common bean by introducing the improved and high yielding varieties could make an important contribution to increase agricultural production and productivity in the area where there is low practice of using improved varieties of common bean. To this end, using the improved common varieties could be one of the alternatives to improve productivity by small farmers. However, production of common bean using the improved varieties is not yet introduced and studied in the target area. Thus, this research work is initiated to investigate the success story of using improved common bean varieties in Irish Aid Operational Technology Dissemination Project Mandate area of Areka Agricultural Research center Tekle. et.al [3].

\section{Preface}

In Southern Nations, Nationalities, and Peoples Region (SNNPR) particularly the project target Woredas are characterized by persistent food insecurity with many farming household not producing enough food and income to meet families' food requirements. Improved agricultural technologies largely focusing on increasing yield and market value have an important role in increasing productivity, income and building household food security. The increased agricultural productivity also boosted by the availabilities and access of new and improved agricultural technologies. Improved agricultural technologies, management practices, and inclusion of resource poor household for enhanced technological access also have a proven track record on improving food security and decreasing susceptibility to individual stresses. Thus, investing in dissemination of improved agricultural technologies is key to improve the livelihood of low-income and food insecure households. By recognizing this, Irish Aid has launched technology dissemination initiative with aims to reducing poverty for poor and marginalized farmers, particularly women; driving agricultural growth by linking poor farmers into new and improved crop, livestock, and natural resource conservation technologies.

The Operational Research Technology Dissemination project (ORTDP) is addressing key agricultural development challenges prioritized by both the Ethiopian and Irish governments: improved food security, poverty reduction and greater gender equity, better nutrition outcomes and more climate resilient food and farming systems through supporting of rural poor household by accessing for improved agricultural technologies. Southern Agricultural Research Institute (SARI) in collaboration with Irish-Aid has been currently investing in agricultural research and dissemination of 
improved agricultural technologies focusing on crop, livestock, and natural resource management. The technologies being disseminated are tested and proven to have potential for up scaling to improve productivity, food and nutrition security, and climate resilience of resource poor farmers. For the past five years, the project has disseminated more than 33 proven crop, livestock, and natural resource management technologies for more than 13266 resource poor household in seven food insecure woredas of the region especially for whose landholding less than 0.25 hectare and women.

The project has reviewed its performance and status to lay out strategic directions and priorities for agriculture technologies dissemination and extension in the region. As one component to address the OR project goal particularly to reduce poverty or improve nutrition, common bean is one of the crop technologies disseminated by the project and its performance has been evaluated giving an account in addressing issues related to productivity, income, nutrition and adaptability to ever changing environment. Of the technologies successfully disseminated by the project, the common bean case studies presented as proven bestbet agricultural technologies and innovations that are available for uptake and up scaling. This case study was conducted in five ORTDP project woredas of common bean disseminated. Farmers for the case study were selected randomly from beneficiary and non-beneficiaries. Thus, from the project woredas 135 farmers were selected of which $80(60 \%)$ farmers were beneficiaries and $55(40 \%)$ farmers' non-beneficiaries. Data collection sheet was prepared to collect quantitative and qualitative data regarding the productivity, income, food, and nutrition, trends on use of improved seed, adoption, and challenges. The data collected was subjected for simple descriptive statistical analysis.

\section{Justification of the Intervention}

Common bean is one of lowland pulses produced on hot regions. It has been known as an export crop for long period contributing to the foreign exchange earnings. It is also grown for home consumption. Common bean is consumed in traditional dishes. In SNNPRS, it is a popular food as "nifro" with maize and it is also consumed with Kocho. Despite its role in the farming system and in supporting the national economy, yield has been low and stagnant for several years. There could be several reasons for this but the most important ones are lack of improved varieties with desirable agronomic practices, low yield potential of local varieties, and diseases. Especially low production and distribution of improved seed is limited among resource poor farmers. Besides this, the access of the improved varieties has been low for poorest farmers. Therefore, ORTDP project has proposed to promote various improved common bean varieties (hawassa dume, and nassir) for five consecutive years and wajo and tatu for the past two years only aimed to improve income, diversify diets, and improves nutritional status of poorest households in six project intervention woredas.

\section{Result and Achievement}

In the last five project intervention years, ORTDP has addressed 1357 resource poor households with improved common bean dissemination, especially for farmers who unable to access improved seeds and had smaller land (farmers their landholding less than 0.25ha). Through revolving seed, more than 1160 households have benefited. Totally, 2517 households are benefited by direct provision and revolving of improved common bean seeds. The project has provided 241 quintals of four improved common bean varieties (hawassa dume, Nasir, wajo and tatu) and popularized on 591 hectare of land throughout the project intervention years. These varieties have been successfully promoted in all woredas using cluster-based approaches accompanying with practical agronomic practice training and its related input as a package. Participatory technology dissemination method and cluster approach was a key element of the implementation of this project. The study in line with Bassa et al. [4], which confirmed enabling poor farmers to use full packages of agriculture through direct provision, capacity building, awareness creation and sustainable supporting the extension system promotes agricultural productivity there by enable the small-scale farmers to be in position of food security and build assed (Figure 1).

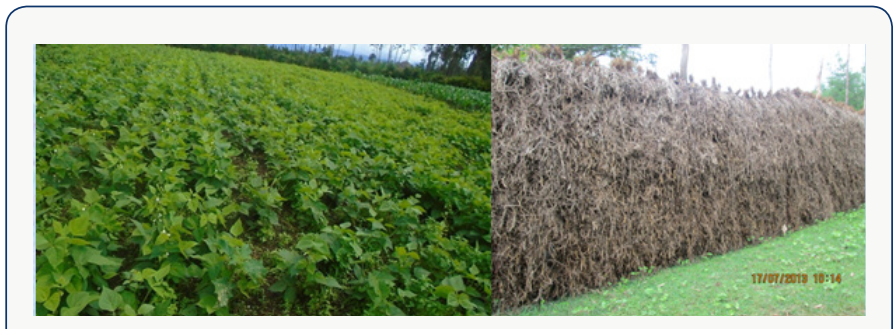

Figure 1: Mean Productivity of common bean Qt/ha before and After project intervention.

\section{Improved Productivity}

Based on the suitability and agro-ecological adaptability of crops ORTDP has disseminated different crop varieties for beneficiaries. While the project proposes four common bean varieties for demonstration, the primary criterion was its contribution to increase of productivity of common bean. The advantages of theses common bean varieties include their high yield potential, early maturity, and nutritional values. Midterm impact evaluation revealed that yields of common bean have increased by $66 \%$ twofold over 4-years period among beneficiaries in comparison to a 30\% increase of mean yield for non-beneficiaries. The increase in productivity mainly attributed the higher productivity of new varieties, slight increase of common bean cultivated land by beneficiaries, and the application of fertilizer (NPS) for common bean, which was uncommon among many farmers in many project 
woredas. The survey report also indicates that $10 \%$ increase in average annual cultivated land per household for common bean (Figure 2).

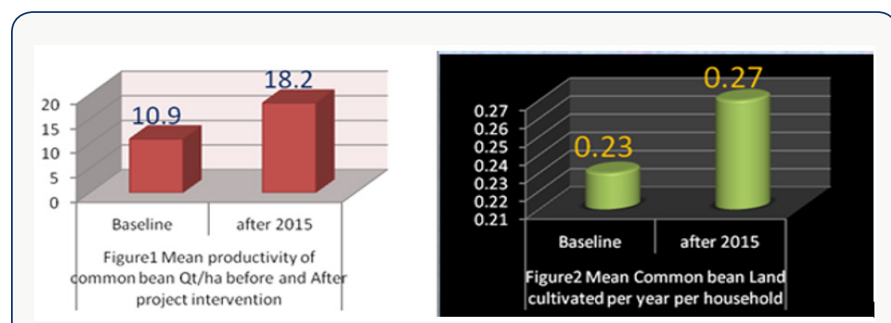

Figure 2: Mean Common bean Land cultivated per year per household.

\section{Food and Nutrition Security}

Increased production has also led to significant improvement in food security and nutrition. As survey report in Figure 3, over $62 \%$ of project beneficiary household consume common bean at least once in a week while only $18.8 \%$ of non-beneficiary household consume common bean at least once in a week. Consumption of common beans was much more prevalent in among beneficiaries, while lesser extent among non-beneficiaries. This indicates that project beneficiaries tend to produce more for food than cash. Through their consumption household can have food nutrients like protein and iron that common bean contains. Caution needs to be taken in interpreting these nutritional results. While it reveal some interesting trends on contribution to nutrition, what is not mean that household access all required food items that meets the nutritional security standards (amount of killo calories per day/week). The data to what extent reflects the availability and access of common bean, which rich in nutrition through their own production. This also have a significant contribution to food security with many nutritional benefits, as it is rich in protein, iron, zinc, and dietary fibre. These constituents contributed to the improvement in food and nutrition and the common bean acceptance by farmers.

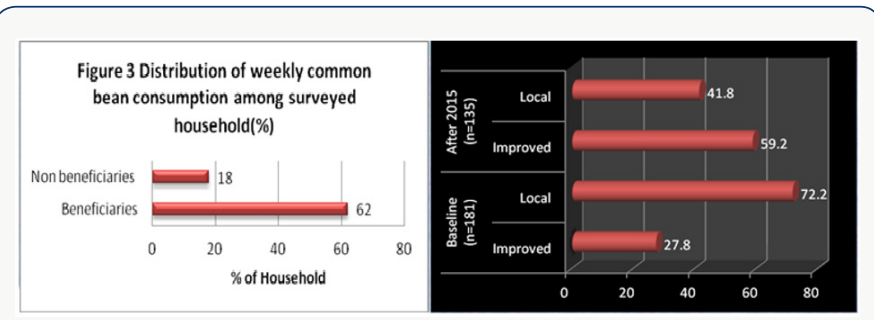

Figure 3: Distribution of weekly common bean among surveyed household(\%).

\section{Improved Income}

Farmers in all woreda use common bean both for cash generation and for home consumption although the majority use for cash. Common bean is grown in both production seasons; belg and meher seasons with the main growing season being belg. Farmers are in great need of cash for the meher season especially wheat and teff producing woreda to buy agricultural inputs like fertilizer and seed. The yield of the new varieties is about two times those of local bean and generated an additional income for household. Therefore, common bean is strategic cash crop, which fulfils the immediate cash demand for input purchase. Moreover these, its short production period, legumness and related soil fertility improvement characteristics increased, and erratic rain fall and relatively less susceptibility to weather change increased the demand of common bean production maximization year to year. During interviewees farmers mentioned that most of the common bean produced during, Belg season is sold to generate income. As indicated in the baseline report, crop income for farmers in SNNPR ORTDP project woreda comes from sale of cereals such as wheat, teff, and sorghum, and during the survey time, the annual income from cereals was 1532 ETB (ORTDP baseline survey report, 2012). After four years of project implementation, the annual mean cash income obtained only from sale of common bean for both project beneficiaries and non-beneficiaries reaches over 3,254 birr per household (Figure 4). The actual mean annual cash income for non-beneficiaries is higher for beneficiaries; this is because when compared to beneficiaries, non-beneficiaries sold more of what they produced.

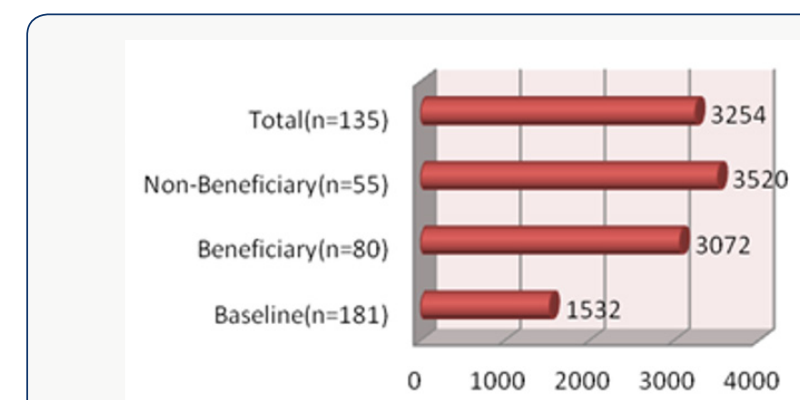

Figure 4: Mean annual income of households from common bean after intervention in Birr.

\section{Technology Adoption}

The common bean varieties disseminated by the project were evaluated against the local variety by using 13 criteria. More than $59 \%$ farmers in the survey districts evaluated Nasir and Hawassa Dume by seed emergence, suitability for inter cropping, seed size, seed color, early maturity, yield, taste, and marketability. Over all rank calculated shows that Nasir and Hawassa Dume have first preference by farmers in the all project location. Both the local and new varieties have the same market demand as they have the same color. Trends on planting of improved common bean varieties in project woredas during base lines ranged from $10 \%$ to $50 \%$ with mean value $27.8 \%$. After four years of intervention, trends on use those common bean varieties has become 59.2\%. Three different successful aspects of the new bean varieties were identified by farmers during the survey: improved taste, higher productivity, and market-preferred attributes reported among both beneficiaries and non-beneficiaries. In addition, drought tolerant and early maturity 
aspects of varieties has also contributed to the better adoption not only project kebele but also in neighboring kebeles. As this was one of the outputs of the operational research programme, and $60 \%$ of households included in the survey were programme participants, it suggests more work has to be done through regular extension in disseminating and promoting of those improved common bean varieties among non-beneficiary household.

\section{Drivers to Success}

As it described in section 2.1 higher productivity, marketability, and compatibility with the color preference of farmers were the main drivers for the successful dissemination of those common bean varieties. Beside this, the project full package approach enables poorest to increase their productivity using fertilizer as a package. The use of fertilizer for the common bean especially NPS were uncommon in most project woredas and the project has tried to demonstrate the yield difference using NPS fertilizer. Moreover, the project's cluster-based technology dissemination and transfer approach played a significant role to easily diffusion of knowledge and practice from one cluster to the other and created a critical mass on disseminated technologies.

\section{Challenges}

Despite the significant contribution of common bean for food security, income and nutrition challenges are remaining. Farmers reported that the susceptibility to disease and pest and less tolerant to flood and heavy rainfall and management problem especially improper application of fertilizer. The significant number of farmers reported that they have not applied fertilizer mainly NPS as recommended rate.

\section{Opportunities for Further Scaling Up}

As indicated above in section 2.4, high productivity, early maturity, its color acceptability, its taste, suitability for intercropping and marketability played a significant contribution for the successful popularization and adoption of common bean varieties disseminated in project woreda as well as beyond project area. Beside this the ever-increasing market demand on common bean, availability of seed at local level, availability of organized seed and marketing system and availability of diverse agro-ecology that suitable for cultivate common bean in the region was the major opportunities to further scale up the common bean technologies in the region.

\section{Key Lesson and Recommendation}

The interventions in agricultural research and dissemination have been strong components in strategies to promote sustainable agricultural development. Previously the technology dissemination approaches were focused on strengthening the productivity aspects of the technologies. Currently the project has disseminated the common bean varieties focused demand of farmers. The project considers the multi-benefits and interactions of common bean technologies disseminated with interest and demands of farmers for technologies. In all project woreda, farmers give equal priority for income generating potential of technology as productivity potential. Therefore, common bean technologies disseminated by the project has great demand by the community for food consumption as well as for income source and is a major crop in the area. A technology, which has great demand by beneficiaries, have multi-benefit and agro-ecologically suitable, ultimately leads to success. The varieties distributed by the project fulfill most of farmers' interest and their production objectives and that is why it became successful.

Therefore, the food and income security of poorest and marginalized people could be enhanced through accessing poorest household for demand driven better yielding and high valued agricultural technologies. Moreover, the project's cluster based technology dissemination and transfer approach played a significant role to easily diffusion of knowledge and practice from one cluster to the other and created a critical mass on disseminated common bean technologies. This approach can bridge the research with extension in more interlinked way and accelerate technology transfer between farmers. In addition, most of farmers prefers to plant common bean as intercropping rather than mono cropping. Their preference varies with the primary objective of farmers. Farmers whose primary objective is for household consumption and have land shortage tends to cultivate as intercropping while farmers with their primary objective for cash tends to cultivate as mono-cropping. Intercropping production of common bean among households having less than 0.25 ha is more advantageous over mono cropping cultivation.

Generally, it can be concluded that farmers demand driven technology dissemination can lead to accelerated technology adoption and knowledge transfer. Dissemination of any research outputs or technologies likes common bean to address multi-fated problem of resource poor farmers can be successful if it considers the primary production interest or objectives of poor farmers and the multi-benefit potential of the technologies. In addition, it was recommended that the greater use of research or technology for income generation might have the greater contribution to speed up improvement of livelihood of resource poor farmers and adoption of the technologies.

\section{Acknowledgement}

The research teams provide acknowledgements and own great appreciation on Ireland Embassy, All Ireland people and its Irish Aid department of foreign affairs for financial support of project implementation and case study successful accomplishment, Addis Ababa, Ethiopia and Southern Agricultural Research Institute and Areka Agricultural Research center for supporting in implementation. 


\section{References}

1. CSA (Central Statistical Agency) (2017) Agricultural sample survey. volume I report on area and production of major crops (private peasant holdings, meher season) Addis Ababa, Ethiopia. 584 Statistical Bulletin 584.

2. Misgana M, Tadeese M (2017) Performance evaluation of common bean variety at Benatsemy Woreda of South Omo zone ,SNNPR, Ethiopia. Agricultural Research and Technology Open access journal. Jinka, Ethiopia.
3. Tekle Yoseph, Getachew Gashaw, Wondewosen Shiferaw, Tibebu Simon, Ermias Mekonnen (2014) Evaluation of Common Bean [Phaseolus Vulgaris (L.)] Varieties, for Yield and Yield Components. Southern Agricultural Research Institute, Jinka Agricultural Research Center, Jinka, Ethiopia, 4(17).

4. Bassa Z, Abera A, Zeleke B, Alemu M, Bashe A, et al. (2017) Success Story and Factors Affecting Level of Income Earned from Improved Potato Farming in Damot Sore Woreda, Wolaita and Southern Ethiopia. Irrigat Drainage Sys Eng 6: 181.

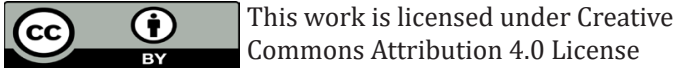

To Submit Your Article Click Here: Submit Article

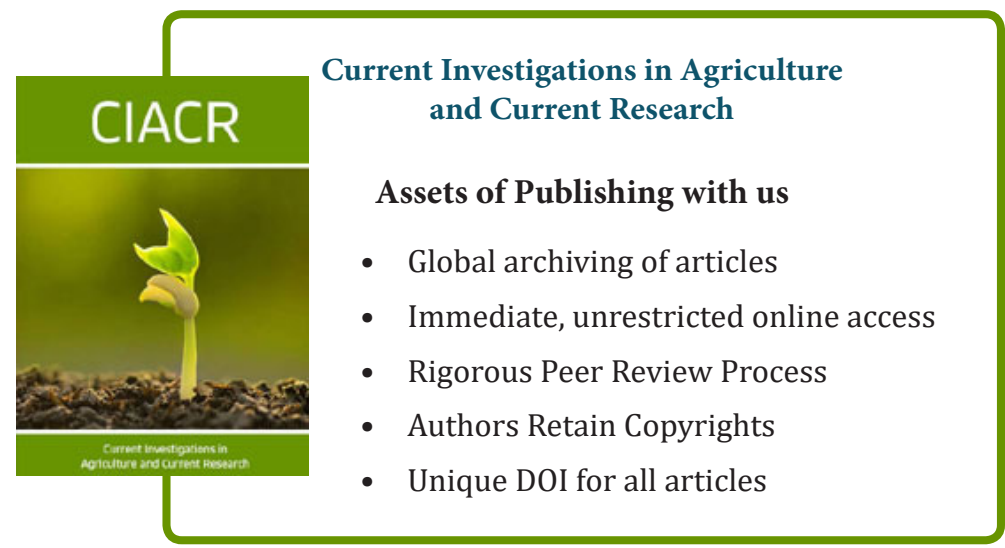

